\title{
SOA Maturity Models: Guidance to Realize SOA
}

\author{
Youcef Baghdadi
}

\begin{abstract}
SOA is an architectural that aims at promoting reuse, integration, composition, flexibility, and agility. However, adopting SOA is a process that needs to be governed in terms of planning, design, realization, and evaluation with a certain level of maturity. There exist many SOA maturity models from both industry and academia, which, with the misconceptions of SOA, gets enterprises confused when deciding SOA adoption. This work first relates some maturity models to Capability Maturity Model Integration for Service. Then it presents a SOA maturity framework to guide the adoption process. This would help an enterprise to: (i) understand SOA adoption, (ii) know its state, (iii) adopt a model or develop its own model, and (iv) govern SOA, namely why, when, and how to progressively move to higher maturity.
\end{abstract}

Index Terms-SOA maturity model, CMMI, framework, SOA adoption process.

\section{INTRODUCTION}

Most organizations understand the need to address Service-Oriented Architecture (SOA) governance during SOA adoption [1]. However, the enterprises engaged (or willing to engage) in SOA effort are lost for many reasons, including (i) misconceptions [2], i.e. for many people, SOA means different things such web services technology or enterprise application integration [3], (ii) the understanding of its drivers [4], [5], or (iii) the methodology to realize it [6], [7] But, the most important reason concerns with the expected benefits (for different categories of stakeholders, including business owners, business managers, and IT people) and the process and the underlying capability and resources used to adopt SOA. Varadan et al. in [1] state "what is not clear is how an organization gets started. What works and what does not work? More importantly, what is required in SOA governance for organizations to see sustained and realized benefits?"

This work advocates that SOA, as an architectural style for both business and IT [8], [9], may be driven by business or IT. Business people expect SOA to promote flexibility of business processes, and agility of the business, whereas IT people expect SOA to reduce the costs by promoting reuse, integration of data, and composition of applications supporting business processes.

Therefore, to adopt SOA for the sake of both business and IT, namely their alignment, an enterprise may start first by preparing its service infrastructure and platform so that its information system becomes a service system that provides different types of services [10]; indeed, as an architecture, SOA main components are services implementing

Manuscript received February 20, 2014; revised April 24, 2014.

Youcef Baghdadi is with the Sultan Qaboos University, Oman (e-mail: ybaghdadi@squ.edu.om). contracts-that should be understood by the consumers and governed by policies to which the consumers adhere. Then, effectively use the service system to make its business processes flexible and responsive to business events of different natures, i.e., different types of customer demands. And finally, seek agility to face changes in business such new model, merging, acquisition, or any transformation that affects its business model or plan. These are different steps of a full SOA adoption process. This process needs to be managed (or governed), i.e. planned, designed, implemented, and evaluated. This governance entails practices and capabilities and requires resources. A set of practices, capabilities and resources express a certain level of maturity of SOA adoption process.

Meanwhile, there exist several models from both industry and academia, which may get enterprise confused when engaging in SOA adoption effort, as each enterprise has its specifics in terms of business model and business processes, and the required resources.

First, we relate some existing maturity models to Software Engineering Institute (SEI) Capability Maturity Model for Service (CMMI® for Services (CMMI-SVC) [11]. Then, we advocate for a maturity framework that emphasizes the aforementioned steps of the adoption process instead of the whole process as recommended by the existing maturity models. Indeed, while business and IT should be aligned, they have different expectations from SOA and consequently different perspectives. The proposed maturity framework considers distinct SOA maturity models for: (1) reuse, (2) integration, (3) composition, (4) flexibility, and (5) agility.

This would help an enterprise to: (i) understand SOA adoption requirements and benefits, (ii) position its maturity to reach certain benefits by adopting SOA, and (iii) plan to progress, in parallel, towards the whole process.

The remainder of the paper is organized as follows: the next section presents some SOA maturity models and relates them to CMMI-SVR. Section III details the proposed framework. Section IV specifies the requirements for SOA adoption.

Finally a conclusion section presents some open issues.

\section{SOA MATURITY MODELS}

SOA maturity models provide an abstract overview of SOA adoption by characterizing evolutionary levels [5]-[12]. They can be thought of as a collection of key practices to optimize a business or IT well-defined architecture. They can be used to control and to measure the progress of SOA adoption [13]. SOA maturity models constitute a management tool to get an overview over SOA and to help during the whole process of SOA adoption. They provide a basis for communication among stakeholders. Most of SOA maturity models are based on CMMI-SVC. 


\section{A. Capability Maturity Model for Service}

The CMMI® model is designed to guide and improve mature service practices, which contributes to the performance of the service provider performance and the satisfaction of the service consumer. For CMMI, a service is "a product that is intangible and non-storable". That is a service is a useful intangible and non-storable result delivered through the operation of a service system. SEI defines a service system as "an integrated and interdependent combination of component resources that satisfies service requirements". Some of these resources can belong to customers or suppliers.

CMM models focus on improving processes in organizations. They describe elements of effective processes and an evolutionary improvement path from ad hoc, immature processes to disciplined, mature processes with improved quality and effectiveness.

Maturity levels are defined as evolutionary process improvement, which helps in predicting the future performance of an organization by describing the range of expected results [11]. The CMMI defines six capabilities levels in the continuous form as shown in Table I.

TABLE I: CMMI MODEL

\begin{tabular}{|c|c|c|}
\hline Level & Name & Description \\
\hline 0 & Incomplete & No process \\
\hline 1 & Performed & Perform base practices to achieve specific \\
goals
\end{tabular}

\section{B. SOA Maturity Models}

Several SOA maturity models do exist in both industry and academia. We first briefly introduce samples of them. We present two maturity models from industry: SIMM by IBM and SOAMM (Wipro Technologies) and two from academia: CSOAMM (Consolidated SOA Maturity Model) and Welke's model. Then, we relate them to CMMI.

\section{1) IBM SOA maturity model: service integration maturity model (SIMM)}

IBM proposed a SOA maturity model Service Integration Maturity Model (SIMM) [14]. The level of de-coupling and amount of flexibility achievable at each stage of maturity are what make up the following seven levels of maturity: 'Silo' (data integration), 'Integrated' (application integration), 'Componentized' (functional integration), 'Simple services' (process integration), 'Composite services' (supply-chain integration), 'Virtualized services' (virtual infrastructure), and 'Dynamically reconfigurable services' (eco-system integration). Each level has a detailed set of characteristics and criteria for assessment as summarized in Table II.
TABLE II: IBM SIMM

\begin{tabular}{|c|c|c|c|}
\hline Level & Description & Benefit/Objective & Explanation/Example \\
\hline 1 & Silo & Data integration & $\begin{array}{c}\text { The organization starts } \\
\text { from proprietary and quite } \\
\text { ad-hoc integration. }\end{array}$ \\
\hline 2 & Integrated & EAI & $\begin{array}{l}\text { The main objective is to } \\
\text { provide Enterprise } \\
\text { Application Integration. }\end{array}$ \\
\hline 3 & $\begin{array}{l}\text { Componenti } \\
\text { zed }\end{array}$ & $\begin{array}{l}\text { Functional } \\
\text { integration }\end{array}$ & $\begin{array}{l}\text { The main objective is to } \\
\text { provide SOA components }\end{array}$ \\
\hline 4 & $\begin{array}{l}\text { Simple } \\
\text { service }\end{array}$ & $\begin{array}{l}\text { Process } \\
\text { integration }\end{array}$ & $\begin{array}{l}\text { This is an early phase of } \\
\text { SOA, where first } \\
\text { web-services will be } \\
\text { published internally or } \\
\text { externally and the } \\
\text { business view of IT } \\
\text { changes from } \\
\text { function-oriented to } \\
\text { service oriented. An } \\
\text { Enterprise Service Bus } \\
\text { (ESB) helps to integrate } \\
\text { services across multiple } \\
\text { applications inside and } \\
\text { outside the enterprise. }\end{array}$ \\
\hline 5 & $\begin{array}{l}\text { Composite } \\
\text { service }\end{array}$ & $\begin{array}{l}\text { Supply chain } \\
\text { integration }\end{array}$ & $\begin{array}{c}\text { The connection between } \\
\text { business processes and } \\
\text { services is the most } \\
\text { important issue. }\end{array}$ \\
\hline 6 & $\begin{array}{l}\text { Virtualized } \\
\text { services }\end{array}$ & $\begin{array}{c}\text { Virtual } \\
\text { infrastructure }\end{array}$ & $\begin{array}{l}\text { Creation of virtualized } \\
\text { services. The architecture } \\
\text { has changed towards a } \\
\text { grid-enabled SOA, } \\
\text { completely technology } \\
\text { neutral. In this level, new } \\
\text { business models are } \\
\text { deployed and old business } \\
\text { models are transformed. } \\
\text { The infrastructure can be } \\
\text { finely tuned with the } \\
\text { overall goal of on demand } \\
\text { business transformations. }\end{array}$ \\
\hline 7 & $\begin{array}{l}\text { Dynamically } \\
\text { reconfigurab } \\
\text { le service }\end{array}$ & $\begin{array}{l}\text { Eco-system } \\
\text { integration }\end{array}$ & $\begin{array}{l}\text { The system can compose } \\
\text { services or applications at } \\
\text { run-time, based on policy } \\
\text { descriptions. }\end{array}$ \\
\hline
\end{tabular}

2) SOA maturity model SOAMM (Wipro technology)

Inaganti and Aravamudan [15] proposed a framework of SOA that is based on a study of other maturity models developed by other industries. Their SOA maturity model is made up of five levels as summarized in Table III: 'Initial services', 'Architected services', 'Business services', 'Measured business services', and 'Optimized business services'. The proposed SOA maturity model takes the following aspects of SOA into consideration to get a full picture of an organization's current level of SOA maturity. These are: (i) Scope of SOA adoption: 'Intra department', 'Inter-department/Business unit', 'Cross business unit', and 'Enterprise/Supply chain', (ii) SOA maturity level; i.e., capabilities of the architecture (e.g., fundamental SOA, networked SOA, process-oriented SOA), (iii) SOA expansion stages, (iv) SOA Return On Investment (ROI), and (v) SOA Cost Effectiveness and Feasibility. For instances, fundamental SOA uses initial services at intra- or inter-department. Networked SOA uses business services by cross business unit, where the ROI is the maintainability. A process enabled SOA uses optimized business services for supply chain. 
TABLE III: SOAMM

\begin{tabular}{|c|c|c|c|}
\hline Level & Description & Benefits/Objectives & Explanation/Example \\
\hline L1 & $\begin{array}{l}\text { Initial } \\
\text { service }\end{array}$ & Functionality & $\begin{array}{c}\text { Provide initial service for } \\
\text { departments }\end{array}$ \\
\hline L2 & $\begin{array}{l}\text { Architected } \\
\text { service }\end{array}$ & Reusability & $\begin{array}{l}\text { Cost effective reusable } \\
\text { services }\end{array}$ \\
\hline L3 & $\begin{array}{c}\text { Business } \\
\text { service }\end{array}$ & $\begin{array}{l}\text { Internal and } \\
\text { external } \\
\text { composition }\end{array}$ & $\begin{array}{l}\text { Provide business service } \\
\text { and collaborative } \\
\text { services to allow business } \\
\text { processes to change } \\
\text { quickly and effectively. }\end{array}$ \\
\hline L5 & $\begin{array}{l}\text { Measured } \\
\text { business } \\
\text { service }\end{array}$ & $\begin{array}{c}\text { Transformation of } \\
\text { business }\end{array}$ & $\begin{array}{c}\text { Transformation of } \\
\text { business from reactive to } \\
\text { a real-time business. }\end{array}$ \\
\hline L6 & $\begin{array}{c}\text { Optimized } \\
\text { business } \\
\text { service }\end{array}$ & $\begin{array}{l}\text { Enterprise nervous } \\
\text { system or automatic }\end{array}$ & $\begin{array}{l}\text { Self-organization of the } \\
\text { enterprise }\end{array}$ \\
\hline
\end{tabular}

\section{3) $\mathrm{CSOAMM}$}

Maier in [12] compared SIMM and SOAMM to come up with a consolidated model CSOAMM (Consolidated SOA Maturity Model) that is made up of 9 levels as summarized in Table IV. The author claims that CSOAMM is not created to be maturity model. It is instead created for a better understanding of the SIMM and SOAMM. CSSOAMM has 10 levels numbered from -2 to 7 to combine SIMM and SOAMM.

TABLE IV: CSOAMM

\begin{tabular}{|c|c|c|c|}
\hline Level & Description & $\begin{array}{l}\text { Benefits/O } \\
\text { bjectives }\end{array}$ & Explanation/Example \\
\hline-2 & Silo & $\begin{array}{l}\text { Same as } \\
\text { SIMM }\end{array}$ & Same as SIMM \\
\hline-1 & Integrated & $\begin{array}{l}\text { Same as } \\
\text { SIMM }\end{array}$ & Same as SIMM \\
\hline 0 & Components & I & $\begin{array}{l}\text { Provide initial, } \\
\text { identifiable } \\
\text { components with } \\
\text { contract and interface }\end{array}$ \\
\hline 1 & Technology Test & I & $\begin{array}{l}\text { Starting point for SOA } \\
\text { adoption, i.e. initial } \\
\text { learning step. }\end{array}$ \\
\hline 2 & $\begin{array}{l}\text { Published Web } \\
\text { services }\end{array}$ & $\begin{array}{l}\text { Compositi } \\
\text { on }\end{array}$ & Integration of processes \\
\hline 3 & Institutionalization & $\begin{array}{l}\text { EAI \& } \\
\text { Compositi } \\
\text { on }\end{array}$ & $\begin{array}{l}\text { Organization-wide } \\
\text { development process }\end{array}$ \\
\hline 4 & $\begin{array}{l}\text { Architected } \\
\text { services }\end{array}$ & $\begin{array}{l}\text { Single } \\
\text { sign-on }\end{array}$ & Return of investment \\
\hline 5 & $\begin{array}{l}\text { Internal and } \\
\text { External Services }\end{array}$ & $\begin{array}{l}\text { Compositi } \\
\text { on }\end{array}$ & \\
\hline 6 & Measured service & $\begin{array}{l}\text { Transform } \\
\text { ation }\end{array}$ & \\
\hline 7 & $\begin{array}{l}\text { Dynamically } \\
\text { reconfigurable } \\
\text { services }\end{array}$ & $\begin{array}{l}\text { Dynamic } \\
\text { architectu } \\
\text { re }\end{array}$ & \\
\hline
\end{tabular}

\section{4) Welke's model}

Welke et al. in [5] proposed a new SOA maturity model that accounts for the different motivations for SOA adoption by IT administrators, business managers, and enterprise leaders. They describe 5 maturity levels as shown in Table V: 'Initial', 'Managed', Defined', 'Quantitatively Manage' and 'Optimized'. Each level has six dimensions or attributes: 'SOA view', 'Benefit and metrics', 'Business involvement', 'Methodology', 'Service sources', and 'Governance'. For instance 'SOA view indicates the maturity progression. They present a framework as SOA maturity cube to: (i) help organizations identifying their current level, and (ii) determine how to progress towards the next level, i.e. from the narrower IT-driven (e.g., infrastructure efficiency, reuse, application composition, data integration) to broader Enterprise-driven (e.g., BP analytics, enterprise flexibility and agility, enterprise transformation).

For Welke et al. [5], an enterprise may start first by preparing its service infrastructure and platform so that its information system becomes a service system. Next, effectively use the service system to make its business processes flexible and responsive to business events of different natures such as different types of customer demands. Then seek agility to face changes in business such new model, merging, acquisition, or any transformation that affect its business model or plan.

TABLE V: WELKE'S MODEL

\begin{tabular}{|c|c|c|c|}
\hline Level & Description & Benefits/Objectives & Explanation/Example \\
\hline 1 & Initial & Promise of reuse & $\begin{array}{c}\text { Fine-grained SW } \\
\text { component and basic } \\
\text { service definition } \\
\text { policies at project level }\end{array}$ \\
\hline 2 & Managed & $\begin{array}{l}\text { Standardization of } \\
\text { data and resources }\end{array}$ & $\begin{array}{l}\text { Services are exposed as } \\
\text { part of project costs, } \\
\text { where service policies } \\
\text { managed by registry } \\
\text { monitors }\end{array}$ \\
\hline 3 & Defined & $\mathrm{BP}$ redesign & BP support \\
\hline 4 & $\begin{array}{l}\text { Quantitatively } \\
\text { Managed }\end{array}$ & $\begin{array}{l}\text { Agility and } \\
\text { Flexibility }\end{array}$ & $\begin{array}{l}\text { Enterprise service } \\
\text { architecture, where } \\
\text { ESB coordinates } \\
\text { intra-and-inter-organiz } \\
\text { ational service and } \\
\text { business and IT } \\
\text { governance metrics } \\
\text { aligned }\end{array}$ \\
\hline 5 & Optimized & Autonomic systems & $\begin{array}{l}\text { Adaptive architecture, } \\
\text { where value-chain } \\
\text { service is optimized } \\
\text { and full integration up } \\
\text { and down the stack by } \\
\text { using policy feedback } \\
\text { used to adjust delivery }\end{array}$ \\
\hline
\end{tabular}

\section{Relationship to CMMI and Remarks}

When we relate the aforementioned models to CMMI, as summarized in Table VI, we note certain confusion due namely to the misconception of SOA and the alignment of business with IT. It mainly indicates that he models do not have the same understanding of the concept of maturity of SOA adoption process. Therefore, a simpler model is required.

\section{GUIDANCE FRAMEWORK TO ADOPT SOA}

Unlike the above-described SOA maturity models that consider SOA adoption as a whole process with different levels of maturity (mostly adopted from CMMI), our proposed maturity framework is built on CMMI-SRV and Welkes' model to advocate for a process made up of three coordinated steps that can run in parallel. The steps map respectively to the objectives, resources, and capabilities of (1) IT people, (2) business managers, and (3) business owners, as depicted in Fig. 1. Indeed, to adopt SOA for the sake of both business and IT, namely their alignment, an enterprise needs 
to have a SOA adoption process that satisfies the objectives of the business owners, the business managers, and the IT people. The business owners are concerned with the business value. The business managers are concerned with the agility of the business and the flexibility of the business processes. IT people are concerned with the service system that allows reuse for cost effective application integration and composition.

TABLE VI: RELATIONSHIP OF THE MODELS TO CMMI

\begin{tabular}{|c|c|c|c|c|c|c|c|c|c|}
\hline Model & $\begin{array}{l}\text { Owner/ } \\
\text { Year }\end{array}$ & Level & Levels & & & & & & \\
\hline \multirow[b]{2}{*}{ CMMI } & \multirow[b]{2}{*}{$\begin{array}{c}\text { SEI } \\
2002\end{array}$} & 6 & 0 & 1 & 2 & 3 & 4 & 5 & 1 \\
\hline & & & Incomplete & Performed & Managed & Defined & $\begin{array}{l}\text { Quantitatively } \\
\text { Managed }\end{array}$ & Optimized & \\
\hline \multirow[b]{2}{*}{ SOAMM } & \multirow[b]{2}{*}{$\begin{array}{l}\text { Sonic } \\
2005\end{array}$} & 5 & L1 & L2 & L3 & L4 & L5 & & \\
\hline & & & $\begin{array}{l}\text { Initial } \\
\text { Service }\end{array}$ & $\begin{array}{l}\text { Architected } \\
\text { Service }\end{array}$ & $\begin{array}{l}\text { Business } \\
\text { Service }\end{array}$ & $\begin{array}{c}\text { Measured } \\
\text { Business } \\
\text { Service }\end{array}$ & $\begin{array}{c}\text { Optimized Business } \\
\text { Service }\end{array}$ & & \\
\hline \multirow[b]{2}{*}{ SIMM } & \multirow[b]{2}{*}{$\begin{array}{l}\text { IBM } \\
2006\end{array}$} & 7 & 1 & 2 & 3 & 4 & 5 & 6 & 7 \\
\hline & & & Silo & Integrated & $\begin{array}{l}\text { Compone } \\
\text { ntized }\end{array}$ & $\begin{array}{l}\text { Simple } \\
\text { service }\end{array}$ & Composite service & $\begin{array}{l}\text { Virtualized } \\
\text { services }\end{array}$ & $\begin{array}{c}\text { Dynamicall } \\
y \\
\text { reconfigura } \\
\text { ble service }\end{array}$ \\
\hline \multirow[b]{2}{*}{ Wipro } & \multirow[b]{2}{*}{$\begin{array}{l}\text { Wipro } \\
2006\end{array}$} & 5 & 1 & 2 & 3 & 4 & 5 & & \\
\hline & & & Initial & Architectured & $\begin{array}{l}\text { Business } \\
\text { Service }\end{array}$ & $\begin{array}{c}\text { Measured } \\
\text { Business } \\
\text { Service }\end{array}$ & $\begin{array}{c}\text { Optimized Business } \\
\text { Service }\end{array}$ & & \\
\hline \multirow[b]{2}{*}{ Welke's } & \multirow{2}{*}{$\begin{array}{l}\text { Welke } \\
2011\end{array}$} & 5 & 1 & 2 & 3 & 4 & 5 & & \\
\hline & & & Initial & Managed & Defined & $\begin{array}{l}\text { Quantitativel } \\
\text { y Managed }\end{array}$ & Optimized & & \\
\hline
\end{tabular}

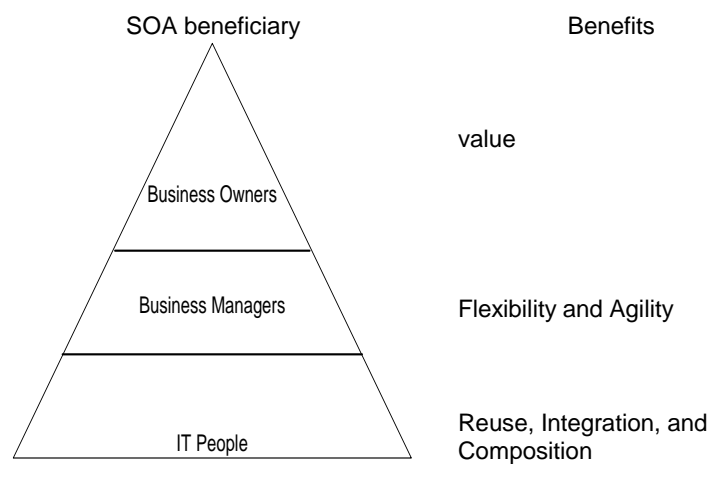

Fig. 1. SOA beneficiaries.

\section{A. The Guidance Framework Specified}

The SOA maturity framework represents the elements of SOA adoption environment, the relationships between the elements and the constraints (if any). The framework is used to guide and constraint a process to adopt SOA. In the following subsections, we first introduce some definitions of SOA and the expectations from its adoption. Then, we specify the framework in terms of elements, relationships and constraints.

\section{1) Service oriented architecture}

SOA has been debated both in the academy and industry. Consequently, there are many definitions of SOA [4], [8], [9], [16]-[19]. For instances, OASIS defines SOA as "a paradigm for organizing and utilizing distributed capabilities that may be under the control of different ownership domains. It provides a uniform means to offer, discover, interact with, and use capabilities to produce desired effects consistent with measurable preconditions and expectations." Cummins in [8] defines SOA as "a business architectural style, where the enterprise is organized into service units." Marks and Bell in [16] define SOA as "a conceptual business architecture where business functionality, or application logic, is made available to SOA users, or consumers, as shared, reusable services on an IT network." In [9] Davies et al. consider SOA as architectural style for both business and IT. Ren and Lyytinen in [18] state "SOA is primarily regarded as a technical architecture consisting of tools and service specification to build loosely coupled applications. At another level it is also a means to leverage flexibility and agility to system services." Welke et al. in [5] note that SOA may be driven by business or IT. From a technology perspective, SOA is commonly thought of as architecture style that builds on loosely coupled, interoperable and composable components or software agents called services. Hirschheim et al. in [19] found that there is a 'disconnect' between the in-print prescriptions regarding SOA and what is actually happening. For example, the vast majority of organizations were using SOA as an IT architectural initiative rather than as a business transformation tool. Perhaps because of this technology focus, most organizations did not see SOA (and services in general) as a vehicle for solving larger business needs, but rather as 'IT things to be consumed by IT.

The misinterpretations of the nature of SOA may impede its adoption [3], [18].

To avoid these misinterpretations, we can characterize SOA and its adoption by some basic, common characteristics:

- SOA is an architectural style. As such, its main components are services implementing contracts that should be understood by the consumers and governed by policies to which the consumers adhere. Originally, SOA involves three actors and three operations. The actors are: service provider, service consumer, and registry, whereas the operations are: publish, find, and bind.

- SOA enables sharing of capabilities provided as services. 
Services in an SOA are modules of business or application functionality with exposed interfaces, and are invoked by messages. Services have well-defined interfaces based standard protocols (usually web-services but most definitions mention that it is not the only possible implementation) as well as quality of services attributes (or policies) on how these interfaces can be used by service consumers.

- SOA may be driven by business or IT as shown in Fig. 1 . For business owners, SOA adds value to all the stakeholders. For business managers, the benefits of SOA are flexibility of business processes, and agility of the business. For IT people, SOA promotes integration of data, composition of applications supporting business processes. The goal of SOA is to increase the alignment between business and IT and achieve business agility the ability to respond to changes quickly and efficiency.

- More importantly, SOA may be adopted progressively in a step-wise process. Each step corresponds to a certain level of maturity. We assume that if SOA adoption process reaches a certain level of maturity, it could align the business with its IT and optimize the value chain.

\section{2) SOA Adoption expectation}

We expect from SOA to allow service reuse, application integration and composition, business process flexibility and business agility

- Reuse: one of the most common reasons for adopting SOA is the possibility of reusing services for cutting cost and saving time, though SOA is more about the ability to change rather than reusing services out of their original context. Reuse is also useful for a SOA transition in an evolutionary process.

- Integration is one of the primary drivers for SOA, as the Enterprise Application Integration (EAI) (i) is data-centric and not process centric, (ii) cannot keep with the business process change, (iii) does not address the business process, and (iv) solutions are very complex and very expensive to maintain. Moreover, business managers seek data and application functionality that cross the existing siloed applications.

- Composition: SOA can be used to compose service in an orchestration or choreography to realize business processes

- Flexibility is responding to the client base changing needs by rapidly reconfiguring the business processes. SOA can play a major role with respect of the presentation and interpretation of data in order to change the execution pattern of business process.

- Agility is rapidly responding to changes in the environment and reacting quickly and efficiently. SOA can be used to sensing the need for change and responding.

Therefore, planning for SOA service delivery requires an anticipation of the needs derived from business process execution flexibility and focusing on servicing data as well as external evaluation data.

\section{3) Elements of the framework}

The elements of the SOA maturity framework are: business owners, business managers, IT people, business model, business process, and service system

a) Business Owners

A business owner is the one who expects a certain value from a business.

\section{b) Business Managers}

Business managers are accountable for describing and designing the architecture of the business, namely the value creation mechanism.

c) IT people

IT people are responsible for the management of the IT infrastructure, platform and applications that support the business processes.

d) Business Model

A business model describes the design or architecture of the value creation and delivery and captures the mechanisms it employs [20]. We consider a value-oriented approach, where the concept of business value is best viewed as a network of services provided by/to customers, partners, suppliers, or regulation authorities, which constitutes a value network (or value chain). In a value chain, value creation is viewed as collaborative, creative, synergistic business processes, where a business process is itself a service of more coarse-grained granularity than the fine-grained IT- services that support it.

\section{e) Business process}

A business process has a value expressed as a service provided to stakeholders, especially customers upon their demands (of different natures). These demands constitute the business events that trigger (initiate) the business process. A set of coordinated, controlled, synergetic activities realize the service. Therefore, a business process has a set of state values (including initial and final state values) that reflect its executions. The business process modeler sets and changes the state values over time when business requirements change. The information system, which is a representation of the assets of the business, namely its business objects (e.g., customers, bill, orders, or items) supports the business processes by providing them with the data they consume. A business object is "a representation of a thing active in the business domain, including its business name and definition, attributes, behavior, relationships, and constraints." (OMG)

\section{f) Service system}

SEI defines a service system as "an integrated and interdependent combination of component resources that satisfies service requirements".

\section{4) Relationships between the elements}

The relationships between the elements of the framework are summarized in Table VII. The most important are shown in Fig. 1.

- Business owners seek value and nominate business managers

- Business managers architect the value creation and manage the business, including its architecture

- IT people design the service system and use SOA for cost effective integration and composition through reuse

- Business owners, managers, and IT people have different expectations from SOA as shown in Fig. 1. 
TABLE VII: RELATIONSHIPS BETWEEN THE ELEMENTS OF THE FRAMEWORK

\begin{tabular}{|c|c|c|c|c|c|c|c|c|}
\hline & $\begin{array}{l}\text { Business } \\
\text { Owner }\end{array}$ & $\begin{array}{l}\text { Business } \\
\text { Manager }\end{array}$ & IT People & Value & SOA & $\begin{array}{c}\text { Business } \\
\text { Model }\end{array}$ & $\begin{array}{c}\text { Business } \\
\text { Process }\end{array}$ & Service System \\
\hline $\begin{array}{c}\text { Business } \\
\text { Owner }\end{array}$ & // & Nominate & & Seek Value & & Evaluate & & \\
\hline $\begin{array}{l}\text { Business } \\
\text { Managers }\end{array}$ & $\begin{array}{l}\text { Are } \\
\text { accountabl } \\
\text { e to }\end{array}$ & // & Nominate & Architect & $\begin{array}{l}\text { Agility } \\
\text { Flexibility }\end{array}$ & $\begin{array}{l}\text { Manage: } \\
\text { Plan, } \\
\text { Architect, } \\
\text { Realize, } \\
\text { and } \\
\text { Evaluate }\end{array}$ & $\begin{array}{l}\text { Manage: } \\
\text { Plan, } \\
\text { Model, } \\
\text { Execute, and } \\
\text { Evaluate }\end{array}$ & \\
\hline IT People & & $\begin{array}{c}\text { Are } \\
\text { accountable } \\
\text { to }\end{array}$ & /I & & $\begin{array}{c}\text { Reuse } \\
\text { Integration } \\
\text { Composition }\end{array}$ & & Support & $\begin{array}{c}\text { Manage: Plan, } \\
\text { Realize, and } \\
\text { Evaluate }\end{array}$ \\
\hline Value & Sought by & & & $/ /$ & & & & \\
\hline SOA & & $\begin{array}{l}\text { Used for } \\
\text { Agility and } \\
\text { Flexibility }\end{array}$ & $\begin{array}{l}\text { Used for Reuse, } \\
\text { Integration and } \\
\text { Composition }\end{array}$ & Adds & // & Agility & Flexibility & Architecture \\
\hline $\begin{array}{c}\text { Business } \\
\text { Model }\end{array}$ & & Managed by & & & & /I & & \\
\hline $\begin{array}{l}\text { Business } \\
\text { Process }\end{array}$ & & Managed by & & & & & /I & \\
\hline $\begin{array}{l}\text { Service } \\
\text { System }\end{array}$ & & & Managed by & Reduces Cost & $\begin{array}{l}\text { Architected } \\
\text { with respect to }\end{array}$ & Supports & Supports & // \\
\hline
\end{tabular}

\section{REQUIREMENTS FOR SOA REALIZATION}

In addition, to enforce the alignment-that requires a direct mapping from the concepts used in business into those used in the supporting IT, we first need to model the business process with services that map directly to IT services in a Model Driven-like process. Then, we transform the information system into service system. Finally, we build the maturity framework, where the service system and the business processes are key, central elements.

\section{A. Service-Oriented Business Process Modeling}

A business process model captures the relevant properties with respect to the above-mentioned definition of business process. Therefore, we model it by using specialized services. Business process modeling emphasizes the separation of concerns that differentiate the activities of control and execution. Similarly, the data packaged into business objects are separated from the state of the business process. Therefore, we specialize a service into controller service, state service, and worker services [21].

The controller service is the central element of our modeling. It oversees a business process execution through its state. The controller service deals only with the control and coordination of the business process. It invokes a state service to retrieve the state of the business process; and accordingly invokes the respective worker services and updates the business process state when any of the worker services terminates its job. The controller service is invoked by an initiator web service. The worker services add value to a business process towards the achievement of its goal. Worker services are provided by business objects. These services are related to each other as follows:

- A business process is associated with an event, a set of business objects, a set of states, including an initial state, and a final state.
- A service may be a controller service, a state service, or a worker service.

- The controller service uses both worker services and state service. The latter provides it with the state of the business process, whereas the former perform the required activity. The initiator worker service uses the controller service.

- The worker services are realized in the information system the business objects, whereas the SS is realized by a specific data structure representing the state values.

\section{B. Transformation of the Information System into Service System}

We propose to use different techniques transform the existing information system into a service system that supports the business processes and make them flexible, namely (i) reverse engineering information systems, including legacy applications and database, and a way to map previous, existing Enterprise Portfolio Services, (ii) extract services from exiting business processes, or (iii) reuse Partner and Provider Services. In this reverse engineering phase, everything becomes services. Later on, a restructuring phase will specialize these services into controller services, state services, or worker services and assign them to their respective real or artifact business objects that play the role of service system [10].

\section{SOA Adoption Process}

The framework guides a SOA adoption process that is made up of three coordinated steps that can run in parallel. The steps map respectively to the objectives, resources, and capabilities of (1) IT people, (2) business managers, and (3) business owners, as depicted in Figure 1 and detailed in Table 7. Indeed, to adopt SOA for the sake of both business and IT, namely their alignment, an enterprise needs to have a SOA adoption process that satisfies the objectives of the business owners, the business managers, and the IT people. 


\section{CONCLUSION}

This work has first developed a framework for SOA maturity. The elements of the framework are business owners, business managers, IT people, value, business models, business processes, and service system. The framework has been used to guide a SOA adoption process. The process is refined with Welkes' model into three coordinated steps that can run in parallel. Each step has a distinct maturity model with respect to CMMI-SRV. The steps map respectively to the objectives, resources, and capabilities of (1) IT people, (2) business managers, and (3) business owners. Indeed, to adopt SOA for the sake of both business and IT, namely their alignment, an enterprise needs to have a SOA adoption process that satisfies the objectives of the business owners, the business managers, and the IT people.

The work advocates for a SOA adoption center to manage and coordinate the three steps.

Unlike the existing SOA maturity models that are hard to implement, the proposed process is simple to understand and manage, including its planning, design, realization and evaluation.

This work is limited to the framework and the process. It does not cover the coordination center and the required management and coordination tools

This work can further developed towards a methodology for adopting SOA, including models and tools.

\section{REFERENCES}

[1] R. Varadan et al., "Increasing business flexibility and SOA adoption through effective SOA governance," IBM Systems Journal, vol. 47, no. 3, pp. 473-490, 2008.

[2] A. R. G. Oz. What is SOA anyway? Getting from hype to reality. [Online]. Available: http://www.rgoarchitects.com/files/SOADefined.pdf

[3] M. Fowler. Service oriented ambiguity. [Online]. Available: http://www.martinfowler.com/bliki/ServiceOrientedAmbiguity.html

[4] P. Bianco, R. Kotermanski, and P. Merson, "Evaluating a service-oriented architecture," Software Engineering Institute Technical Report, September 2007.

[5] R. Welke, R. Hirschheim, and A. Schwarz, "Service-oriented architecture maturity," IEEE Computer, vol. 56, pp. 61 - 67, 2011.

[6] Y. Baghdadi, "A methodology for web services-based SOA realization," Int. Journal of Business Information Systems, vol. 10, no. 3, pp. 264-297, 2012.
[7] Y. Baghdadi, "A survey on approaches to identify and develop Web-enabled services with respect to service-orientation and SOA: Towards a value-oriented approach," Int. Journal of Computer Applications in Technologies, vol. 45, no. 1, pp. 1-14, 2012.

[8] F. A. Cummins, Building the Agile Enterprise with SOA, BPM and $M B M$, The Morgan Kaufmann/OMG Press, 2010.

[9] J. Davies, D. Schorow, S. Ray, and D. Rieber, The Definitive Guide to SOA: Oracle Service Bus, Apress, 2008.

[10] Y. Baghdadi and R. P. Castillo, "Service retrieval for service-oriented business processes modeling," Communications in Computer and Information Science, vol. 417, pp. 151-163, 2013.

[11] SEI, Capability Maturity Model Integrated for Service, 2011.

[12] F. Meier, "Service oriented architecture maturity models: A guide to SOA adoption," MS thesis, Hohskolan Skovde, 2006

[13] M. Niemann, J. Eckert, N. Repp, and R. Steinmetz, "Towards a generic governance model for service-oriented architectures," in Proc. 14th Americas Conference on Information Systems, Toronto, Canada, 2007.

[14] A. Arsanjani and K. Holley. (2005). Increase flexibility with the service integration maturity model (simm). [Online]. Available: http://www-128.ibm.com/developerworks/webservices/library/ws-soa -simm/

[15] S. Inaganti and S. Aravamudan. (2007). SOA maturity model. [Online]. Available: http://bpmg.orgwww.bptrends.com/publicationfiles/04-07-ART-The $\%$ 20SOA\%20MaturityModel-Inagantifinal.pdf/

[16] E. A. Marks and M. Bell, Service-Oriented Architecture (SOA): A Planning and Implementation Guide for Business and Technology, Wiley, 2006.

[17] A Reference Model for Service Oriented Architecture, Organization for the Advancement of Structured Information Standards (OASIS), Billerica, MA, 2006.

[18] M. Ren and K. J. Lyytinen. (2008). Building enterprise architecture agility and sustenance through SOA. Communications of AIS. [Online]. 22(4). Available: http://aisel.aisnet.org/cais/vol22/iss1/4.

[19] R. Hirschheim, R. Welke, and A. Schwartz, "Service-Oriented architecture: Myths, realities, and a maturity model," MIS Quarterly Executive, vol. 9, no. 1, pp. 37-48. 2010.

[20] D. J. Teece, "Business models, business strategy and innovation," Long Range Planning, vol. 43, no. 2/3, pp. 172-194, 2010.

[21] Y. Baghdadi, "Modeling business processes with service: Towards agile enterprises," Int. Journal of Business Information Systems, vol. 15 , no. 4 , pp. $410-433,2014$

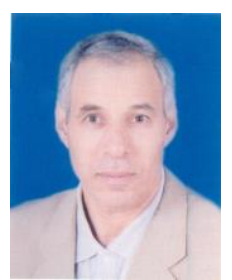

Youcef Baghdadi holds a $\mathrm{PhD}$ in computer science from University of Toulouse I, Toulouse, France. He is now an associate professor at Sultan Qaboos University. He had published papers in many journals such as Theoretical and Applied Electronic Commerce Research, Enterprise Transformation, and Service Oriented Computing and Applications. His research interests include web services and service oriented architecture, enterprise interactions, electronic 